\title{
Editorial
}

\section{Atlantic Geology Turns 50 - a Tribute to the Past and a Look to the Future}

This year, 2014, marks the publication of Volume 50 of Atlantic Geology, which was originally named Maritime Sediments and subsequently Maritime Sediments and Atlantic Geology. In early volumes of the journal it was customary for the editor to write a preface or "Editor's remarks". We are returning to that custom for this volume only, and as the longest-serving current editor, it seems appropriate that I provide a summary of the journal's history before many of the details fade into obscurity.

Atlantic Geology has the unusual distinction of being the journal of a regional scientific society, the Atlantic Geoscience Society. And it is financially viable, a rare achievement for a small scientific journal. This happy situation results from the foresight, insight, and dedication of a number of individuals over the years. My main goal in this editorial is to pay tribute to these people, on behalf of both AGS and myself because in one way or another, those individuals also have had significant influences on me. Also, by coincidence I have been part of the geoscience scene in Atlantic Canada for virtually all of the time that the journal has existed.

\section{BIRTH OF A JOURNAL (1965 - 1966)}

Atlantic Geology started life as more of a newsletter than a journal. The concept was developed in the summer/fall of 1964 by Daniel Stanley and Donald Swift (both at Dalhousie University), Bernard Pelletier (at Bedford Institute of Oceanography, BIO), and Deryck Laming (at the University of New Brunswick, UNB). The focus was on recent and ancient sediments of the Maritime Provinces, and hence the name Maritime Sediments.

The first issue of Volume 1 was published in early 1965, with Daniel J. Stanley as editor and four associate editors with affiliations and areas of expertise listed as follows: Deryck Laming (UNB), sedimentology; Bernard Pelletier (BIO), recent sediments and marine geology; Paul Schenk (Dalhousie), ancient sediments; Donald Swift (Dalhousie), Pleistocene, economic, and groundwater geology. In that first issue, the editor wrote that the role of the journal was to provide an informal means of communication for geologists engaged in any facet of research on recent or ancient sediments in the Atlantic Provinces of Canada and adjacent regions. He noted that this area of study was growing rapidly, and keeping up on all the diverse work underway was difficult; finding out who was doing what and avoiding duplication were problems, as were the "great distances involved" and lack of personal contact. I think that advances in technology, AGS colloquia and improved travelling conditions now enable us to be more aware of other geoscientists' research, but in spite of that, communication can still be a problem.

Those first issues were printed with assistance from the Atlantic Provinces Inter-University Committee on the Sciences and the Association of Atlantic Universities, although I gather from a conversation with Daniel Stanley that the financial contribution may not have been large, barely enough in one instance to cover a $\$ 10$ fine for a traffic violation incurred while en route to pick up the printed copies!

For the 4 issues of Volume 2 (1966), Deryck Laming took over as editor, the idea being that the editorship would rotate among the associate editors, whose number grew to six with the addition of Michael Keen from Dalhousie University. During the early years, the journal was more like a newsletter, with summaries and overviews of research activities by the editor, associate editors, and others. By coincidence, my first geology-related summer job was in 1966 with Deryck Laming, one of my professors at UNB. I well remember working in the introductory geology lab at the university collating pages for Maritime Sediments. Deryck was a major influence on my life as he was also the supervisor of my BSc honours thesis on "Recent Sediments in Cardigan Bay, PEI". Regrettably, he left UNB at the end of my third year, before I had completed my thesis. From Deryck I learned how to (and how not to) go about doing research, and I have always been grateful to him. 
THE PELLETIER YEARS (1967 - 1980)

In 1967, Bernard Pelletier ${ }^{1}$ became editor, likely because all three of the other founders of the journal had left the region. To celebrate Canada's centennial, the colour of Maritime Sediments' cover was changed from blue-green to red and white, "the official colours of the Canadian Parliament", according to the editorial in the first of 3 issues in the 1967 volume. The cover also included a stencil of the centennial maple leaf "to commemorate the 1967 volume as our centennial project", again quoting from the editorial. With Volume 3, a subscription rate of $\$ 3$ for individuals and $\$ 6$ for institutions was also implemented, the first two volumes having been free for the reading, and the number of issues per volume decreased from 4 to what was probably a more manageable and realistic 3 .

Under Bernard Pelletier's editorship, both the content and quality of the journal "began to assume a different complexion" in the words of subsequent editors George Pajari and Ron Pickerill in a 1981 editorial. It evolved from a newsletter style of publication to a true journal, although the papers were not refereed. Bernard's editorials during those years documented the ups and downs of the journal, and changes were frequent. In 1973 (Volume 9) the layout was changed to two columns, with text on both sides of the page, a format being adopted by many journals: according to the editorial - as always, Maritime Sediments was keeping up with the times! Bernard introduced the concept of always starting each article on the right-hand side of the page, a format that we continue to follow. Those important changes in 1973 were made possible by the acquisition of a grantin-aid of publication from the National Research Council of Canada.

In 1975 (Volume 11), Bernard Pelletier wrote about the expansion of the scope of the journal to include more regional aspects of Atlantic and Appalachian geology, "while still publishing progress reports, accounts of meetings, and other items of current interest." Although Deryck Laming had written in a 1966 editorial that Maritime Sediments "is not and we expect never will be, a place to publish final results" which the editors expected to be "published elsewhere in a recognized scientific journal", Bernard Pelletier was rapidly steering Maritime Sediments in just that direction.

By 1978 (Volume 14), subscription rates had reached the lofty sum of $\$ 4.50 /$ year for individuals and $\$ 9.00 /$ years for institutions. So-called "separates", a vital aspect of publishing in the pre-electronic age, were $\$ 3.00 /$ page for 100

\footnotetext{
${ }^{1}$ Bernard Pelletier died May 20, 2013, in Ottawa, Ontario, Canada, at the age of 89.
}

copies. The rates could be kept low, because of continued help from the National Research Council grant.

But change was in the wind. In Volume 16 (1980), Pelletier announced that he was stepping down as editor. Although he did not say why in his editorial, the decision was likely linked to his move from Dartmouth to Ottawa. In the editorial he thanked a number of people, including: Carolyn Frost and Ferne McCoombs, who typed all the manuscripts; his daughters, who helped with clerical work; Franco Medioli, Michael McMullen, and Georges Drapeau, who provided editorial help; and the printer J. Oliver Woods. He also acknowledged the role of the Geological Survey of Canada and Bedford Institute of Oceanography, which had served as headquarters for the journal. The tone of the editorial was that it would be the last issue of Maritime Sediments.

\section{THE MIDDLE YEARS (1981 - 1985)}

In some ways, Bernard Pelletier was more prescient than he realized. Maritime Sediments had come to the end of its life but it was to be reborn as Atlantic Geology and Maritime Sediments. Thanks to Darlene Pajari's amazing memory and record-keeping, we know that on November 27, 1980, Bernie Pelletier met with Ron Pickerill, George Pajari, and perhaps most importantly, Darlene, George's wife. The motivation for this meeting was that Ron and George had agreed to be the new editors, with Darlene becoming the managing editor. About $\$ 1850$ was transferred to the new editors to close the Maritime Sediments bank account, and the transfer date was set for 1 January, 1981. In her role, Darlene did all the typing and layout, handled finances, paid bills, and kept records - all on a volunteer basis. We owe Darlene a huge debt of gratitude for playing such a major role in keeping the journal alive.

With Volume 17 (1981), the name of the journal became Maritime Sediments and Atlantic Geology and a blue-striped pattern was adopted for the cover. The new editors wrote "With the addition of 'Atlantic Geology' not only do we anticipate publication of research in non-sedimentological fields, but also we hope that eventually, submitted material will come from both sides of the Atlantic", another prescient statement that has since come to pass. A major advance was that the journal became refereed, albeit not in the usual way. As described in the Instructions to Authors at the time, prior to submission the author had to obtain at least two reviews from "competent critics", who could not be from the author's institution. The author was expected to revise the manuscript according to the comments and suggestions of these reviewers, or explain why not, and the reviewers 
had to agree to be identified as such in the published paper. The original reviews had to be submitted with the paper, which was then evaluated by the editors and editorial board to determine if it should be accepted for publication. Additional revisions might be required at that stage. As an author who published in this system, I can attest that one's chosen "competent critics" could be very critical indeed, as could the editors and associate editors, and that papers published under that system were indeed well reviewed! Another feature of the journal introduced at this time was the inclusion of a French translation of the abstract; for many years this was done by Denis Fillion. Today, it is done through cooperation with the New Brunswick Department of Natural Resources.

Behind the scenes it was a difficult time for the journal. Although the Atlantic Geoscience Society was supportive, a Forward in Volume 17 (1981) by Alistair MacKay (then AGS president) makes it clear that the relationship was informal, and that Maritime Sediments and Atlantic Geology was not an AGS journal. In October of 1981, Darlene and George Pajari moved to Toronto to take over the family business and, for the next few years, the journal was produced in Ontario. Another difficulty arose in 1983, when Ron Pickerill announced in an editorial in Volume 19 that the Natural Sciences and Engineering Research Council had withdrawn funding from the journal. The annual grant of \$3000-4000 had been used to assist with printing and distribution costs and helped keep the subscription prices at a reasonable level. Perhaps even more annoying than the actual loss of the funding was the NSERC comment that papers published in Maritime Sediments and Atlantic Geology could equally well be published by "other Canadian journals in the earth sciences area”. In 1985, George and Darlene Pajari stepped down as editor and managing editor, respectively.

Foreseeing the difficulties, Graham Williams and I were by then talking to Ron Pickerill about a new team of editors, and we all agreed to ask the Atlantic Geoscience Society to take on the journal as its own. As explained by then-AGS president Aubrey Fricker in a letter published in the journal, in 1986, the society agreed to accept Maritime Sediments and Atlantic Geology as its official journal beginning in 1987, and appointed Ron, Graham, and me as co-editors. President Fricker wrote "On behalf of the Atlantic Geoscience Society, I am glad to express the support of our members for the three appointed editors and encourage them in putting the journal on a sound and secure scientific and financial footing." I think that we succeeded in doing that and we have never had to ask AGS for any financial support, an impressive achievement.

\section{BECOMING THE AGS FLAGSHIP (1986 - 2006)}

After a transitional year in 1986, Volume 23 (1987) was the first volume that was truly the "Journal of the Atlantic Geoscience Society". The journal's headquarters moved to the Acadia University Institute, housed in the basement of War Memorial Residence at Acadia University. Darlene Feener did the layout and looked after printing and, unlike Darlene Pajari, she was paid for her work, albeit part-time. In the early years, Aubrey Fricker managed the financial aspects of the journal. Circulation gradually increased and purchase of reprints was popular, both helping to defray expenses.

Having a board of associate editors from a wide spectrum of disciplines to assist in reviewing papers, soliciting manuscripts, and generally lending their good name and credibility to the journal was continued, as it is today. This system implemented by the journal's founders has always worked well. It has never been the task of that board to handle article reviews - that is done by the editors themselves - but they are advisors in times of problems. In this respect, I am pleased that Bernard Pelletier was still an associate editor at the time of his death in May, 2013, fulfilling a request that he had made to me many years before.

After much soul-searching as to what the impact on subscriptions might be, but wanting to recognize the broad scope of the journal, the name was changed to Atlantic Geology in 1989. In March 1991, we received the good news that we were successful in again obtaining a modest grant-in-aid of publication from NSERC. We applied for and obtained the grant annually until the end of 1996 when NSERC discontinued that programme.

After those years of stability through much of the 1990s, further changes were necessitated in at the end of 1998, when Darlene Feener moved on to fulltime work off the Acadia campus, so could no longer handle the management of layout and printing. At the same time, loss of space in War Memorial Residence required the journal to move into the Department of Earth and Environmental Science, where it had to occupy a much reduced archival space, initially in a workshop area in the basement and ultimately in the back room of Rob Raeside's research lab on the $3^{\text {rd }}$ floor. However, by that time (2006) a digital archive had been made (see below), and the required space is now just a few shelves in a bookcase.

Fortunately, after Darlene's departure in 1998, David McMullin, now an instructor in the Department of Earth and Environmental Science at Acadia, took over the 
responsibilities of layout and printing and also became financial manager. He continued in that role until the end of 2006, when Chris White of the Nova Scotia Department of Natural Resources assumed the new role of Production Manager. At the end of 2000, Graham Williams stepped down as co-editor but fortunately he was able to persuade his equally-talented-at-editing colleague Rob Fensome to step in to take over his role, and the transition was smooth.

\section{INTO THE ELECTRONIC ERA (2007 - NOW)}

During these years, the printing of the journal was also changing dramatically. With the move of journal operations to Wolfville in 1987, Kentville Publishing in New Minas had taken over the printing. However when it became clear that the publishing world was changing and we needed to do layout electronically, we started to work with Gary Dunfield and Andrew Steeves who had founded Gaspereau Press in Kentville. This proved to be an excellent strategy as they did both layout and printing, and the subsequent success of Gaspereau Press attests to the fact that they are very good at both. In 2009, Gaspereau Press told us that they had become too successful (i.e. busy with bigger jobs) to continue to do layout for us. Luckily, we found Alexander (Sandy) Lugar, then of Coldbrook, NS, but now working in Saskatchewan, to take over doing layout on a part-time basis, an arrangement which continues today.

It is impossible to summarize all the decisions and the steep learning curves that accompanied these changes. Suffice it to say that by 2006 when Chris White joined the journal, it was apparent that we could not afford (financially or logistically) to continue to print and distribute the journal in the longer term. By chance, I heard about a new group known as the Electronic Text Centre, affiliated with the Harriett Irving Library at the University of New Brunswick. They were using open source software for maintaining journal websites on a commercial basis, and Atlantic Geology was one of the first journals to be accepted in the program. We thought about continuing to print but decided that it would be the worst of both worlds - hence, we bit the bullet and went fully digital. We were one of the first journals to take this route but now there are many. It is less expensive, easier, and very efficient. We have not completely abandoned printing - once a year Gaspereau Press prints about 35 copies for those subscribers who still want them and are willing to pay for the full cost of printing and mailing.
After the Halifax 2005 GAC-MAC conference, we made a request to AGS and the organizing committee for the conference that some of its share of the surplus from the meeting be used to digitize the archives of the journal. Hence all are now available on the website, and the journal is "open access" from Volume 1 onward, except for the most recent 3 volumes, which are accessible by subscription only.

At the end of 2007, Ron Pickerill stepped down as editor, and was replaced by Simon Haslett of the University of Wales (Cardiff). This move was to cover an area of geoscience not represented by the other two editors, and to try to move toward publishing more papers from the other side of the Atlantic Ocean, a vision of editors Ron Pickerill and George Pajari when they changed the name of the journal in 1981. We have had some success in attracting such papers, but not as much as we would like. In 2011, Atlantic Geology appointed a $4^{\text {th }}$ editor, David West (Middlebury College, Vermont) with the goal of increasing contributions from the USA and have had some success but would like more.

It is not possible to mention all of the individuals who have contributed to the journal's success over the past 50 years, in particular the associate editors and of course the many authors who continued to submit their work to the journal, even when all was not running smoothly. And we have been fortunate in being the Atlantic Geoscience Society's journal for almost 30 years.

As for the next fifty years of Atlantic Geology - who can say? I know that they won't all involve me but I hope that at least a few of them will!

\author{
Sandra Barr \\ Co-editor, Atlantic Geology \\ 1986 - present
}

\section{ACKNOWLEDGEMENTS}

Jean-Daniel Stanley, George Pajari, and Darlene Pajari kindly shared some of their reminiscences with me during the preparation of this editorial. I thank Rob Fensome and Graham Williams for helpful comments and suggestions on the draft manuscript. 